\title{
Economic Transition and Elections in Poland
}

\author{
By: John E. Jackson, Jacek Klich, and Krystyna Poznańska
}

William Davidson Working Paper Number 391

June 2001 


\title{
Economic Transition and Elections in Poland
}

\author{
John E. Jackson \\ Dept of Political Science and William Davidson Institute \\ University of Michigan, Ann Arbor, MI, USA \\ jjacksn@umich.edu \\ Jacek Klich \\ School of Business and School of Public Health \\ Jagiellonian University, Kraków, Poland \\ uuklich@cyf-kr.edu.pl \\ Krystyna Poznańska \\ Warsaw School of Economics, Warsaw, Poland \\ kpozna@sgh.waw.pl
}

\begin{abstract}
Poland's economic and political transition, one of the most successful transitions, has depended very heavily on the job creation in new firms to replace the jobs lost in the formerly state-owned enterprises. This uses evidence from both survey and aggregate data to analyze four Polish elections during the transition. These analyses indicate that these de novo firms, the individuals they employ, and the residents in the local areas where they exist become an important constituency supporting pro-reform political parties and constraining the actions of parties less sympathetic to the reforms. The creation of this political constituency helps explain how countries can successfully pursue both economic and political reforms.
\end{abstract}

Key words: Poland; economic and political transitions; voting and elections.

\footnotetext{
* Paper prepared for the WDI/CEPR Annual Conference on Transitional Economies, Portoroz, Slovenia, June, 23-26, 2001. This work was supported in part by a grant from the Charles Stewart Mott Foundation to the University of Michigan and while Jackson was a Fellow at the Center for Advanced Study in the Behavioral Sciences. The opinions expressed in this paper are the authors own and not those of their respective institutions or the Charles Stewart Mott Foundation and the CASBS.
} 


\section{Introduction}

Accomplishing economic reform and democratization simultaneously is a daunting task, as many writers have observed. (See Hellman, 1998.) Yet, with varying degrees of success a number of countries are accomplishing this feat, while some that seem unable to make the transition. A central factor contributing to economic success is the country's ability to encourage and support the de novo firm creation and growth, what Schumpeter called creative destruction. (See Caballero and Hammour, 2000; Kornai, 2000.) The Polish transition, often cited as one of the successful transitions, has depended very heavily on the job creation in new firms to replace the jobs lost in the formerly state-owned enterprises. (See Jackson, Klich and Poznańska, 2000a, Winiecki, 2000.) This paper presents evidence from the Polish elections during the transition that these de novo firms, the individuals they employ, and the residents in the local areas where they exist become an important constituency supporting pro-reform political parties and constraining the actions of parties less sympathetic to the reforms. The creation of this political constituency helps explain how countries can successfully pursue both economic and political reforms.

A previous paper (Jackson, Klich and Poznańska, 2000b) used evidence from the 1993 Polish elections to argue that these creative economic activities have important political implications in that they nurture a small but potentially growing constituency that supports pro-reform parties and candidates. The votes for pro-reform parties can directly help the pro-reform party gain seats in the legislature, depending upon the particular election rules in place. Indirectly, the existence of this constituency, combined with the imperative to continue to win elections, constrains the actions of non-reform parties that otherwise might pursue policies that restrict or reverse the reforms. The ability of this emerging constituency to articulate its interests, to advocate for proreform policies, and to constrain the actions of incumbent parties depends upon a number of factors, such as the political rules governing elections and representation and the actions of party leaders in choosing different coalition strategies. We use the Polish elections in the period 1991 to 1997 to demonstrate four related points: the emergence of a pro-reform constituency based on the growth of new enterprises; the support this constituency gives to pro-reform parties; the consequences of different electoral rules and party strategies for how well this support is translated into parliamentary seats; and that the growth of this new economy constituency effects the policies of all parties, not just the pro-reform parties.

The paper begins with a brief summary of findings on the role of de novo firm creation in the development of market economies. The emphasis in this discussion is on the implications of this process for the development of a pro-reform political constituency. This is followed by an analysis of survey and election return data to show the development of such a constituency and 
their support for parties committed to further reform. The third section shows how the rules governing the allocation of parliamentary seats affects the political influence accorded the proreform parties. In the Polish case, the pro-reform party pushed for the adoption of rules that effectively weakened their influence relative to that of parties opposing reforms. We also show that the actions of party leaders in making, or not forming, political coalitions in response to these rules have a substantial bearing on the fortunes of reform parties. We end with a brief discussion of the current party maneuverings and actions being taken in preparation for the elections to be held in September, 2001. These actions demonstrate the importance of this new constituency and how a variety of parties are trying to capture its support.

\section{Creative Destruction and Pro-Reform Interests}

Caballero and Hammour (2000, p. 11) contend that, "The evidence of extensive, ongoing job flows that are pervasive throughout the economy and constitute a major mechanism of productivity growth points to the centrality of creative destruction in the growth process." Poland is certainly no exception. We report in other work (Jackson, Klich and Poznańska, 2000b) that based on data from the Polish Central Statistical Office (GUS) the birth and growth of new and small enterprises employing over five workers in 1997 added about 2.4 million jobs to the Polish economy between 1990 and 1997. Further, the Foundation for the Promotion of Small and Medium Sized Enterprises estimates that in 1997 there were nearly 1.5 million firms with zero to five employees and these enterprises employed 2.3 million workers (Dzierżowski, 1999). Combining the estimates from the two data sources suggests that 4.6 million jobs were created in firms started after the transition began or in private firms with less than one hundred employees in 1990. The creative process contrasts sharply with the destruction that took place among the enterprises that were state and collectively owned and the large private firms (those employing more than 100 workers) existing in 1990. This set of enterprises showed a net loss of close to four million jobs, and gross job creation of only about seventy-five thousand jobs.

Statistical analyses of birth, survival and growth rates revealed a number of interesting relationships between regional characteristics and variations in these rates. One result was particularly relevant to the development and articulation of interest supporting the continuation of economic reforms. There were sizeable agglomeration effects, particularly for births of

\footnotetext{
${ }^{1}$ The gross job creation and destruction estimates suggest a net job creation in the Polish economy, which is inconsistent with the persistently high unemployment rate. This obvious discrepancy can arise from a number of sources. One is overly optimistic job creation figures in one or the other data set. It is also likely that individual Poles are now holding more than one job, so that the number of individuals employed is not expanding as fast as the number of jobs.
} 
domestically owned manufacturing firms. Controlling for the total private sector employment, birth rates were positively related to the number of existing firms. (This finding is consistent with other results from a disparate set of sources, see Arthur, et. al, 1987, Arthur, 1990, Jackson and Thomas, 1995, and Krugman, 1991. Nowak, Urbaniak and Zienkowski, 1994, present a similar finding specifically for Poland.) The implication of this result is that the creation of new economic activity, and the jobs and earnings it represents, will be regionally concentrated in areas where private firms already exist. In the Polish case, this primarily means in the larger, urban areas, such as Warszawa, Kraków, Gdańsk, Poznań, etc.

The proposition in our earlier paper is that the creation of these new firms and the successful transition to the transformed economy they represent will be accompanied by the development of voters with an interest in continuing or even accelerating the economic reforms. Data from the Polish General Social Survey (Cichomski and Morawski, 1998) can be used to track the changing level of support for the new private sector. ${ }^{2}$ The variable combines responses to two questions create a measure of respondents' confidence in private economic firms relative to state-owned firms. This variable ranges from zero to one, with one indicating a great deal of confidence in private firms and hardly any confidence in state firms and zero just the opposite. ${ }^{1}$ There are two important hypotheses represented in these data. The first is that at the aggregate level this confidence should increase as the new private sector becomes more successful. The second is that at the micro level, people employed in new private firms should express more confidence in private firms than people employed in enterprises remaining in the state sector, and this category should be expanding over time.

Table 1 shows the proportions of the respondents in the lower and upper parts of the distributions and the gap between the two. The lower tail consists of respondents who expressed hardly any confidence in private firms and some or a great deal of confidence in state firms. People in the upper tail say they have some or a great deal of confidence in private firms and hardly any confidence in state firms. Confidence in private firms eroded substantially following

\footnotetext{
${ }^{2}$ The specific advantage of the PGSS study is that the questions and survey methodology are fairly consistent over the time so that any observed changes are more likely to be reflecting changes in the electorate than in survey methodology. The exception is that researchers experimented with question structure in half the 1997 survey. We have adjusted the variable definitions to account for these differences. In the experiment half the respondents received the previous question and half were asked the new format. This split sample allows us to compare response patterns and to then adjust the responses to the new formats accordingly.

${ }^{3}$ The precise question is: "I am going to name some institutions in this country. Would you say you have a great deal of confidence, only some confidence, or hardly any confidence at all in them, don't know?" State Firms; Private Firms."
} 
the hardships of the early 1990's at the beginning of the transition. By 1997, when the aggregate economy was improving and there was substantial evidence of new firm creation and growth confidence began to improve.

Part B of the table shows that the proportion of respondents with themselves or a spouse employed in private non-farm enterprises, in joint stock companies, or in state or cooperative

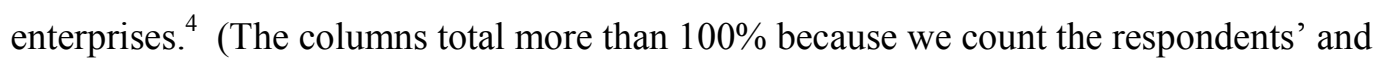

Table 1: Confidence in Private v. State Firms and Ownership of Employer

\begin{tabular}{lrrrrr}
\hline A. Confidence Measure & 1992 & 1993 & 1994 & 1995 & 1997 \\
\hline \% with Low Confidence & $23.8 \%$ & $30.3 \%$ & $32.3 \%$ & $33.4 \%$ & $29.7 \%$ \\
\% with High Confidence & $12.3 \%$ & $8.6 \%$ & $6.7 \%$ & $7.1 \%$ & $9.7 \%$ \\
$\quad$ Gap & $11.5 \%$ & $21.7 \%$ & $25.6 \%$ & $26.3 \%$ & $20.0 \%$ \\
B. Ownership of Respondent & & & & & \\
Employer & $18.9 \%$ & $16.4 \%$ & $19.5 \%$ & $20.6 \%$ & $23.3 \%$ \\
$\quad$ Private Firm (non-farm) & $7.7 \%$ & $9.2 \%$ & $14.4 \%$ & $14.3 \%$ & $16.0 \%$ \\
$\quad$ Restructured Firm & $74.3 \%$ & $75.3 \%$ & $67.6 \%$ & $67.6 \%$ & $62.7 \%$ \\
$\quad$ State or Cooperative Enterprise & $4.4 \%$ & $5.5 \%$ & $6.6 \%$ & $8.6 \%$ & $14.0 \%$ \\
C. \% Employed in New Firms (>5 & & & & & \\
employees)
\end{tabular}

spouses' employment.) The biggest employment change was in the proportion in joint stock companies, which are enterprises in the process of privatization. There was a large decline in the proportions working in state enterprises, and a modest increase in employment in private firms, which includes self-employment. We argue that it is the relative size of these three groups that contributes to the support or opposition to reforms. Part $\mathrm{C}$ in the table shows the proportion of the workforce employed in firms begun since 1990 or that existed in 1990 but employed fewer than one hundred workers. Both parts $\mathrm{B}$ and $\mathrm{C}$ are included to illustrate the growth in the size of the de novo sector, and its potential for developing a pro-reform constituency.

Not surprisingly, respondents in families with employees in the private sector express far more confidence in the private sector than do workers in other ownership sectors. Appendix A shows the relationships between the confidence variable and a number of explanatory variables. On the zero to one confidence scale, respondents where both members worked for a private employer had an expected confidence that was 0.12 higher than respondents with both members in the state sector. The magnitude of this relationship contrasts with other relationships, which

\footnotetext{
${ }^{4}$ Unemployed individuals are counted in these categories as the question refers to current or most recent employment. The omitted category is respondents or spouses who have never worked.
} 
are on the order of 0.01 or 0.02 for females, those living in villages, or an unemployed person. What may be surprising is that there is no difference in confidence between respondents working for state firms and those working for joint stock companies. This latter group's confidence in the private sector matches that of workers in state firms.

\section{De Novo Job Creation and Elections}

The remainder of the paper examines the Polish elections from 1991 to 1997 to test the proposition that job creation in new firms forms an element of a pro-reform constituency and to examine how the electoral rules affected the relative influence of this constituency. To anticipate our findings in this section, at the level of individual voters making choices among the competing parties and candidates and at the level of voting returns by election district (voivodship) these new economic interests play a consistent role in Polish elections. 5 There is a high degree of stability in voters' positions on key issues and on how these issues relate to voting patterns. At the aggregate level, the variations in vote shares across voivodships exhibit quite stable relationships with variables describing the economic and social characteristics of these districts, again suggesting an important continuing role for this constituency.

\section{Polish Elections: 1991-1997}

Poland conducted three parliamentary elections, 1991, 1993 and 1997 and one presidential election, 1995, between 1991 to $1997 .^{6}$ There is a considerable degree of continuity to the major issues during this period. In 1991, the major issues were the role of the Catholic church in Polish civil and political life and the role for former Communist leaders. Some parties, most notably the post-Communist SLD, were also campaigning against the effects of the stringent macro-economic policies adopted by the incumbent reform coalition led by the UD. By 1993 the liberal reform economic policies and their consequences had become a major issue. These three issues - the role for the church and church teachings, the political access for former Communists, and the pace and direction of economic reforms - would be the major political fault lines though with different degrees of emphasis through all four elections. (For extended discussions of the 1993 election, see Chan, 1995 and Powers and Cox, 1997. Slay, 1994, and Tworzecki, 1996, have good discussions of the 1991, 1993 and 1995 elections.)

\footnotetext{
${ }^{5}$ Poland has 49 voivodships.Two were split into subdistricts for electoral purposes. Because data are not available for areas smaller than a voivodship the statistical analyses combine the districts in Katowice and in Warszawa into single districts that matches the voivodship.

${ }^{6}$ The 1990 presidential election is excluded from our analysis.
} 
The configuration of contending parties and candidates was much less stable through these elections. Table 2 shows the major parties and candidates and their shares of the votes in each elections. Twenty-nine parties won seats in the parliament in 1991, which led to a succession of short lived governments between 1991 and 1993. The UD, the largest member of the coalition governments between 1991 and 1993, was identified as the party most strongly supporting liberal economic reforms, though there were divisions in the party between the economic liberals and social democrats. The KLD was a minor coalition member that consistently supported the liberal reforms. These two parties merged in 1994 to form the UW after the KLD failed to win any seats in the 1993 election. The UW's candidate for president in 1995 was Jacek Kuroń, who came from the social democratic wing of the party. He was a highly visible and respected individual, but placed third in the first round of the election, surely caught between the candidacies of the incumbent Lech Wałęsa and the post-Communist and SLD leader Aleksander Kwaśniewski.

\begin{tabular}{lllll}
\hline \multicolumn{5}{l}{ Table 2: Major Parties and Vote Shares } \\
\hline Party/Candidate & 1991 & 1993 & 1995 & 1997 \\
\hline UD/Kuroń & 12.3 & 10.6 & 9.2 & \\
KLD & 7.5 & 4.0 & - & \\
UW (UD + KLD) & & & & 13.4 \\
SLD/Kwaśniewski & 12.0 & 20.4 & 35.1 & 27.1 \\
PSL/Pawlak & 8.7 & 15.4 & 4.3 & 7.3 \\
Catholic & 8.7 & 6.4 & - & \\
PC/BBWR/Wałęsa & 8.7 & 5.4 & 33.1 & \\
Solidarity Trade Union & 5.1 & 4.9 & - & \\
AWS (Catholic + Solid & & & & 33.8 \\
Trade Union) & & & & \\
UP/Zieliński & 2.1 & 7.3 & 3.5 & 4.7 \\
KPN/Olszewski/ROP & 7.5 & 5.8 & 6.9 & 5.6 \\
\hline
\end{tabular}

The SLD and the PSL are two so-called post-Communist parties because their leaders had been party officials in the Communist party before 1989. They formed the governing coalition from 1993 to 1997. The SLD is a broad coalition, including the former Communist trade union, the OPZZ. In 1991 the SLD campaigned strongly against the economic reforms and in favor of state intervention to protect Poland's heavy industry (See Tworzecki, 1996, p. 59). Their economic platform became less opposed to the economic reforms with each election, though they were continually seen as opposing the reforms and even now their economic leaders disparage the UD policies promoted by Balcerowicz (see Kołodko, 2000). The SLD leader in 1993, Aleksander Kwaśniewski, successfully ran for the presidency in 1995, defeating the Solidarność 
icon Lech Wałęsa in a very close second round. The PSL is an agriculturally and rurally based post-Communist party. It strongly opposed the economic reforms and campaigned strongly in favor of continued subsidies for farmers and state-owned firms. The PSL leader, Waldemar Pawlak, was the first Prime Minister in the SLD-PSL coalition government and was a minor candidate for President in 1995.

The right-wing parties were an amalgam of organizations remaining from Solidarność that with the exception of 1997 could not unite into a single coalition. One group of parties, led by the $\mathrm{ZChN}$, were church related and advocated a strong role for the Catholic church and its teachings and strongly pushed the ban on abortions favored by church leaders. The ZChN was part of the governing coalition in 1993, but chose to run as part of a Catholic coalition party in 1993. This coalition did not receive enough votes to win seats in the Parliament following that election. Wałęsa's presidential campaign made a strong appeal to these parties and their supporters. There were independent organizations loosely associated with Wałesa that contested the 1991 and 1993 elections. These were the Center Alliance (PC) in 1991 and the BBWR in 1993. Each received enough votes to have a small bloc of seats in the parliament but each evaporated before the next election. The trade union arm of Solidarnośc tried to run as its own party in 1991 and 1993 and was part of the coalition government in 1993. They strongly opposed the economic reforms and their defection from the coalition in 1993 led to the fall of the last UD led government. They did not receive enough votes in 1993 to gain seats. Prior to the 1997 elections the trade union leader, Marian Krzaklewski, organized the AWS coalition that united the trade union and Catholic parties. This coalition won a plurality of the votes in 1997 and formed a coalition government with the UW that lasted until the summer, 2000 when the UW left.

The UP is included as a separate party even though it remained a small party, eventually losing it base after 1997, and never joined either of the governing coalitions after 1993. It is an interesting party, taking positions opposing economic reform and the role of the church that easily matched those of the SLD yet was strongly anti-Communist, reflecting the roots of some of its leaders in the Solidarność movement. The UP hoped to build its base on voters who opposed the reform, but who would not vote for the SLD because of its Communist background. As evidenced in Table 2, this strategy did not prove to be very viable.

Lastly, there have been a series of small but strongly nationalistic parties that manage to win a small portion of the vote and a few seats in parliament. In addition to their nationalism, these parties advocated a very populist economic program in opposition to the liberal reforms, were strongly anti-Communist and generally were sympathetic to the church leaders. The KPN most vocally pushed this platform in 1991 and 1993, after which it lost its influence. Even though the 
KPN continued to exist as a party, its influence was taken over by the ROP, led by Jan Olszewski. Olszewski ran for the presidency in 1995 and then led the ROP in the 1997 elections. There were attempts to get the ROP to join the AWS coalition, where there would have been agreement on many policies, but Olszewski chose to run separately.

This abbreviated description of the major issues and various parties and candidates contesting each election should help predict the likely vote choices of individuals supporting the economic reforms and with strong confidence in private firms. These people are most likely to support the UD/UW party and Kuroń's presidential candidacy. We can expect them to be unlikely to support the SLD, the PSL and the UP among the left parties and the Solidarity Trade Union on the right. In the choice between Wałęsa and Kwaśniewski in the presidential election, they are most likely to support Wałesa rather than the SLD leader. The pro-reformers may be somewhat ambivalent about the Catholic parties, who did not support the liberal reforms but who did not take highly visible positions on the economy.

\section{Individual Vote Choices}

We first analyze individual vote choices for the various elections using data collected as part of the Polish General Social Survey (Cichomski and Morawski, 1998). The individual data allow us to relate vote choices to specific attitudes that cannot be observed at the aggregate level. With the survey data, the dependent variable is the log-odds the person said they voted for one of the competing parties relative to the UD or the UW in the 1991, 1993 and 1997 parliamentary elections and for one of the presidential candidates relative to Jacek Kuron in the 1995 election. The shortcoming of the survey data is that these assessments of how people voted are based on their recall, in two instances with a definite time lag between the election and the survey. $\square$

The central variable in our analysis of individual vote choices is the one measuring respondents' confidence in private relative to state firms. We would expect variations in this attitude to be strongly related to individual vote choices, particularly as the transition proceeds and as economic issues begin to be an important part of the political debate. Two other attitude variables are included because they capture the other main areas of conflict among the major parties and candidates in the Polish elections during the 1990's. Economic considerations were not the only cleavage in the Polish electorate. People were divided over the role to be played by the Catholic church and by the influence to be accorded former Communist party officials. Two

\footnotetext{
${ }^{7}$ Comparing the marginal distributions in the survey responses with the actual vote distributions suggests that most differences are likely just sampling error, with the exception of a larger reported not voting (or don't recall) than the actual proportion of registered voters not voting.
} 
additional questions tap these dimensions. One asked respondents their assessment of Communism as a form of government and a second whether churches have too much or too little political influence 8 In addition to these three attitude variables we include several variables to capture specific aspects of each campaign and party strategy. Two variables indicate whether respondents are farmers and/or live in a rural village. We expect these variables to be strongly related to votes for the PSL, which is an agriculturally and rurally based party. We also include variables to indicate if respondents live in the home district of one of the parties' leaders or candidates to capture any localized campaign effects. Voters' recall of which party or candidate they voted for in each of Poland's elections between 1991 and 1997 are related to their responses to these variables. The full estimated models are shown in Appendix B.

Our interest is in the association between people's confidence in private firms relative to state owned firms and their vote choices. Table 3 shows the expected difference in vote probabilities between representative respondents who don't know how much confidence they have in both private and state firms (scored a .5) and ones who have a great deal of confidence in private firms but are still uncertain about their confidence in state firms (scored a 0.83). Q $_{\text {This representative }}$ respondent is not a farmer and does not live in a rural village. (This would comprise between sixty five and seventy five percent of the voters in each of the surveys.)

There are a number of important comparisons in this table. Economic considerations played only a small role in the 1991 election, which was held after the start of the stringent reforms but before the full scope of the social costs became apparent. Subsequent to that election, the differences in likely vote choices associated with these different confidence levels are fairly substantial and consistent. Respondents with more confidence in private firms were more likely to vote for the UD+KLD/UW and less likely to vote for the SLD and to a lesser extent the UP. They were also more likely to vote for Kuroń or Wałęsa and less likely to vote for Kwaśniewski in the presidential election. There is a modest trend in increasing support for the UD/UW as confidence increases, which is accompanied by deceasing support for the Solidarity Trade Union/AWS over time. The 1995 Presidential election is a bit anomalous, as the contest in the

\footnotetext{
${ }^{8}$ The questions are: "Thinking about all different kinds of governments in the world today, which of these statements comes closest to how you feel about Communism as a form of government? Worst Form; Bad, but no worse than some; Good for some countries; Good Form; Don't Know" and "Do you think that churches and religious organizations in this country have far too much power, too much power, about the right amount of power, too little power, or far too little power, don't know?"

${ }^{9}$ In the analyses in Tables 3 and 4 the 1991 and 1993 votes for the UD and the KLD are combined and treated as a single party, as they were after formation of the UW in 1994.
} 
first round quickly became a contest between Kwaśniewski and Wałęsa for entry into the runoff. Many pro-reform voters were not confident about Wałęsa's policies, but saw him as preferable to Kwaśniewski, the post-Communist leader. (Some portrayed this election as a choice between yesterday and the day before yesterday, referring to both candidates as being tied more to Poland's past than to its present or future.) This led to a considerable amount of strategic voting with people voting for their second or third preference rather than their first preference, based on candidate viability. Our interpretation of these results is that from 1993 onward, people's confidence in private relative to state-owned enterprises played an important, though not determinative, role in vote decisions and that this role was relatively stable over these three elections. The coefficients on the other attitude variables indicate that attitudes toward Communism and assessments of the influence of church organizations also played a large role in these elections. (For more on the church role in 1993, see Powers and Cox, 1997.)

\begin{tabular}{lccccccc}
\hline \multicolumn{7}{l}{ Table 3: Confidence in Private Firms and Expected Vote Differences } \\
\hline Parliament & UD+KLD & SLD & PSL & UP & Catholic & Solidarity & Other \\
\hline President & Kuroń & Kwaśniewski & Pawlak & Zieliński & Wałęsa & & Other \\
\hline 1991 & & & & & & & \\
Conf $=0.83$ & 0.500 & 0.036 & 0.016 & 0.051 & 0.069 & 0.110 & 0.218 \\
Conf $=0.5$ & 0.488 & 0.057 & 0.016 & 0.041 & 0.057 & 0.111 & 0.228 \\
Difference & 0.012 & -0.022 & 0.000 & 0.010 & 0.012 & -0.001 & -0.010 \\
1993 & & & & & & & \\
Conf $=0.83$ & 0.390 & 0.098 & 0.036 & 0.078 & 0.035 & 0.029 & 0.333 \\
Conf $=0.5$ & 0.279 & 0.176 & 0.071 & 0.099 & 0.024 & 0.053 & 0.297 \\
Difference & 0.111 & -0.078 & -0.035 & -0.021 & 0.010 & -0.024 & 0.037 \\
1995 & & & & & & & \\
Conf $=0.83$ & 0.167 & 0.257 & 0.002 & 0.032 & 0.445 & & 0.097 \\
Conf $=0.5$ & 0.105 & 0.358 & 0.002 & 0.038 & 0.396 & & 0.101 \\
Difference & 0.061 & -0.101 & 0.000 & -0.006 & 0.049 & & -0.005 \\
1997 & & & & & & & \\
Conf $=0.83$ & 0.381 & 0.126 & 0.021 & 0.050 & & 0.317 & 0.105 \\
Conf $=0.5$ & 0.254 & 0.169 & 0.026 & 0.067 & & 0.388 & 0.096 \\
Difference & 0.127 & -0.043 & -0.005 & -0.017 & & -0.071 & 0.008 \\
\hline
\end{tabular}

\section{Election Returns}

The second part of our analysis examines the actual voting returns by district in the 1993 , 1995 and 1997 elections. There are two relevant questions. The first is the role played by new economic activity in building support for pro-reform parties, which will offset some of the 
opposition to the reforms generated by the economic hardships. This proposition is measured by the ratio of jobs created in de novo firms to the total workforce in each voivodship. The second question is again the stability of the relationships between vote shares for each party and the variables representing the variations in preferences on the basic issues - economic reform, antipathy towards former Communist officials, and the role of the Catholic church. The full estimated models are presented in Appendix C. The key results are that the coefficients relating vote shares to education levels, church attendance, and new job creation are relatively stable over these three elections, despite the maneuverings of the different parties and coalitions. These results are consistent with the analysis of individual vote decisions and indicate that across the three elections, the electorate is using the same issues to evaluate these parties and candidates and to make their vote choices.

Our key findings are shown in Table 4, which is the expected change in national vote proportions for each party if there had been a fifty percent increase in the number of new jobs

between 1990 and the year of the election. ${ }^{10}$ (Predict \% is our prediction of the parties' vote share under this scenario and Actual \% shows the percentage they received in the election.) Increasing rates of job creation in new firms would have increased the UD+KLD/UW vote shares while decreasing those of the SLD and other parties in the parliamentary elections and increased Wałęsa's share relative to Kwaśniewski's. Swings of a few percentage points may not seem large, but in the context of Polish elections these differences could have been significant. We will explore the whole question of how vote shares translate into the distribution of seats in the Sejm in a subsequent section, but simply suggest now that shifts of this magnitude can shift a significant number of seats. In the 1995 presidential election, the predicted vote shifts would have offset Kwaśniewski's margin of victory and given the election to Wałęsa.

\footnotetext{
${ }^{10}$ This is a substantial number of new jobs, but is useful for illustrative purposes. Relatively modest increases in the rates of birth, survival, and growth of new firms could yield such an increase in the number of new jobs over four to eight years. See Jackson, et. al. 1997.

${ }_{11}$ Table 4 and Appendix $\mathrm{C}$ refer to the first round of the election, but analysis of the second round produced a coefficient that predicted an even larger vote shift. Given that Kwaśniewski's margin second round margin was $3.4 \%$, a small shift in votes would have altered the outcome.
} 


\begin{tabular}{lccccccc}
\hline \multicolumn{7}{l}{ Table 4: Job Creation in New Firms and Expected Vote Differences } \\
\hline Parliament & UD+KLD & SLD & PSL & UP & Catholic & Solidarity & Other \\
\hline President & Kuroń & Kwaśniewski & Pawlak & Zieliński & Wałęsa & & Other \\
\hline 1993 & & & & & & & \\
Actual \% & 0.146 & 0.204 & 0.154 & 0.073 & 0.064 & 0.049 & 0.311 \\
Predict \% & 0.178 & 0.192 & 0.147 & 0.074 & 0.068 & 0.046 & 0.295 \\
Difference & 0.032 & -0.012 & -0.007 & 0.001 & 0.004 & -0.003 & -0.016 \\
1995 & & & & & & & \\
Actual \% & 0.092 & 0.351 & 0.043 & 0.035 & 0.331 & & 0.147 \\
Predict \% & 0.098 & 0.333 & 0.036 & 0.036 & 0.358 & & 0.139 \\
Difference & 0.006 & -0.018 & -0.007 & 0.001 & 0.027 & & -0.008 \\
1997 & & & & & & & \\
Actual \% & 0.134 & 0.271 & 0.073 & 0.047 & & 0.338 & 0.136 \\
Predict \% & 0.159 & 0.259 & 0.075 & 0.047 & & 0.340 & 0.121 \\
Difference & 0.026 & -0.013 & 0.002 & -0.001 & & 0.001 & -0.015 \\
\hline
\end{tabular}

Both the individual and aggregate analyses indicate that since 1991 economic considerations related to the development of new enterprises have been an important and consistent aspect of voters' evaluations of parties and candidates and of their voting decisions. Furthermore, individual attitudes have been relatively stable over this period, with most change resulting from the systematic changes in the economy. ${ }^{12}$ Confidence in the private sector declined during the period of highest unemployment and then began to recover in 1997 as more jobs were created in de novo private firms and as the economy recovered. This analysis suggests that this economic success did not particularly benefit the incumbent parties, but as people gained confidence in the private sector and as more new jobs were created they were more likely to support the pro-reform party, which was part of the opposition between 1993 and 1997.

\section{Pro-Reform Interests and Representation}

The creation of a pro-reform constituency is a necessary but not a sufficient part of choosing a pro-reform government. The method for allocating seats in parliament once votes have been cast is a critical concern. In any system, but particularly in a parliamentary system such as Poland's, the electoral rules creating voting and parliamentary districts and determining how votes are converted to seats for these districts has a critical bearing on what influence pro-reform

\footnotetext{
${ }^{12}$ Statistical analyses of the three attitude questions used in the individual voting models indicated that other than year to year changes represented by dummy variables for each survey, there was no statistical difference in the relationships between individual characteristics and attitudes across the surveys.
} 
interests can exert on national policy. It is at this point that the findings about the clustering of new enterprises and the agglomeration effects become important. The locational effects lead to the new business creation being concentrated in certain areas. A consequence of this clustering is that the pro-reform voters will also be concentrated rather than being widely distributed across the country. How districts are drawn and how seats are apportioned will affect the representation of pro-reform interests. This section examines the implications of different districting and seat allocation formulas by studying the different boundaries and rules Poland has used or might use in the next election.

A critical set of rules was adopted prior to the 1993 election at the urging of the coalition led by the UD. There were three critical rules designed to reduce the representation of smaller parties and to push consolidation of the parties -- parties had to attain 5\% and coalitions $8 \%$ of the national vote in order to hold seats in the new Sejm; there would be a national list of 69 seats allocated to parties with more than $7 \%$ of the national vote; and the d'Hondt formula would be used to allocate seats among the parties within each voivodship. The latter formula is one of the least proportional means of allocating seats within a proportional representation system and heavily rewards the party or parties with the largest share of the votes within any district. (See Benoit, 2000, for a discussion of the different allocation rules.) Further, the deviation from proportionality increases as the number of seats to be allocated decreases, which in turn advantages the party or parties with their base in the rural, smaller, voivodships, which had fewer seats per district. Since the rural areas were the least successful in stimulating the creation of new firms, this advantage in seat allocations favored the parties opposing reforms, primarily the PSL.

We want to demonstrate the representational implications of these rules by exploring how seats might have been distributed in 1993 and 1997 if there had been different rules. The two changes examined are larger representational districts and a more proportional seat allocation rule. Both these changes are part of the election reform law passed this spring to govern the 2001 election, so our analysis is also a preview of what these changes may mean for that election. In 1999 the forty-nine voivodships that formed the basis for allocating seats in 1993 and 1997 were consolidated into seventeen larger voivodships. For the sake of our analysis, we will assume that these new, larger voivodships formed the districts for the 1993 and 1997 elections and that the number of seats in these districts equaled the sum of the seats in the old districts being combined. ${ }^{13}$ With this scenario we want to see how reducing the disparity in the number of seats

\footnotetext{
${ }^{13}$ Though the voivodships are not perfectly matched to respresentational districts, see fn. 5, we treat them as such for analytical purposes in 1997. In 1993 we use the actual districts as we have
} 
per district might alter the distribution of seats. Our expectation is that this reduction in the number of small districts will make the seat allocation more proportional to vote shares. The second change is the replacement of the d'Hondt rule with the Sainte-Laguë method for allocating seats. Benoit (2000) concludes that the Sainte-Laguë is both the most proportional and the least favorable to large parties among all proportional representation formulas. The use of this seat allocation formula rather than the d'Hondt method should also make the seat allocations more closely match the vote shares. Both these rule changes should favor the smaller parties relative to the larger parties and bring the distribution of seats much closer to the distribution of votes.

\begin{tabular}{|c|c|c|c|c|c|c|}
\hline Party & All Votes & Maj Vote $^{\mathrm{a}}$ & Act. Seats & New Voiv. & St.-Laguë & Both \\
\hline \multicolumn{7}{|l|}{1993} \\
\hline SLD & & & 171 & 157 & 150 & 146 \\
\hline$\%$ & 20.4 & 31.5 & 37.2 & 34.1 & 32.6 & 31.7 \\
\hline PSL & & & 132 & 116 & 112 & 113 \\
\hline$\%$ & 15.4 & 23.7 & 28.7 & 25.2 & 24.3 & 24.6 \\
\hline UD & & & 74 & 75 & 78 & 77 \\
\hline$\%$ & 10.6 & 16.3 & 16.1 & 16.3 & 17.0 & 16.7 \\
\hline UP & & & 41 & 49 & 54 & 51 \\
\hline$\%$ & 7.3 & 11.2 & 8.9 & 10.7 & 11.7 & 11.1 \\
\hline KPN & & & 22 & 31 & 32 & 36 \\
\hline$\%$ & 5.8 & 8.9 & 4.8 & 6.7 & 7.0 & 7.8 \\
\hline BBWR & & & 16 & 28 & 30 & 33 \\
\hline$\%$ & 5.5 & 8.3 & 3.5 & 6.1 & 6.5 & 7.2 \\
\hline \multicolumn{7}{|l|}{1997} \\
\hline AWS & & & 201 & 186 & 173 & 179 \\
\hline$\%$ & 33.8 & 38.8 & 43.7 & 40.4 & 37.6 & 38.9 \\
\hline SLD & & & 164 & 150 & 149 & 143 \\
\hline$\%$ & 27.1 & 31.1 & 35.7 & 32.6 & 32.4 & 31.1 \\
\hline UW & & & 60 & 70 & 73 & 72 \\
\hline$\%$ & 13.4 & 15.3 & 13.0 & 15.2 & 15.9 & 15.7 \\
\hline PSL & & & 27 & 33 & 45 & 39 \\
\hline$\%$ & 7.3 & 8.4 & 5.9 & 7.2 & 9.8 & 8.5 \\
\hline ROP & & & 6 & 19 & 18 & 25 \\
\hline$\%$ & 5.6 & 6.4 & 1.3 & 4.1 & 3.9 & 5.4 \\
\hline
\end{tabular}

vote return data for the districts within Warszawa and Katowice. Also, there is not a perfect mapping of the old voivodships to the new ones, but the boundaries of the new voivodships very 
The possible consequences of the shifts to the new rules can be illustrated by exploring what the distribution of seats would have been in 1993 and 1997 if either or both these changes had been in place in those elections. Table 5 shows the proportion of the all votes received by each party, the proportion of the votes received only by parties allocated seats and the proportion of seats under the different scenarios. 14 (For this discussion, the votes for the KLD are not added to those for the UD, as they were in the previous statistical analysis.) The distribution of seats under the d'Hondt formula with the large number of smaller voivodships produced the results most skewed in favor of the larger parties. Either moving to a fewer number, and therefore larger, districts or adopting the Saint-Laguë formula would have led to a higher correspondence between the proportions of votes and seats. Under the Sainte-Laguë formula, in 1993 the SLD and PSL combined would have lost forty-one seats, with the UP, KPN and BBWR gaining most of these. In 1997, the AWS would have lost twenty-eight seats and the SLD fifteen with the PSL being the biggest gainer, with eighteen new seats. Adopting both changes provided further movement towards equal proportions. The remaining difference between the vote and seat proportions is attributable to the presence of the national list of seats, which only went to parties receiving more than seven percent of the vote, reducing the seats for the minor parties in each election.

Eliminating the national list, as will also be done in 2001, would have favored the smaller parties with less than seven percent of the vote even more. It is easy to conclude that had the rule and districting changes been in effect in 1993 and/or 1997 they would have led to a different relationship between votes and seats and different seat allocations in the two parliaments.

\section{The Decline of the Pro-Reform Party}

One might well ask why the UD/UW's electoral fortunes declined so consistently since their large majority in 1991 to the point they may well not be able to seriously contend in the 2001 elections, given the amount of de novo firm and job creation in the Polish economy and our evidence about the contribution of this activity to building a pro-reform constituency and voting group. Part of the answer offers some insight into the dynamics of politics following economic and democratic reforms. Other parts are rooted in the idiosyncracies of Polish politics and

closely match the boundaries of the older ones, meaning that our assumption is an excellent approximation, certainly for the expositional purposes of this paper.

${ }^{14} \mathrm{We}$ are assuming that individuals would have voted for the same parties under these "new" rules as they did under the actual system. This is very likely an appropriate assumption with respect to changing the number and size of the voivodships. With respect adopting the SainteLaguë formula we have to assume either that there was no strategic voting, which is a difficult assumption given the $5 \%$ and $8 \%$ thresholds, or that there would have been the same amount of 
political leadership in the aftermath of the Solidarność success. This is not the place to try to untangle the second part, but we can offer some observations on the first part. We point to two factors -- an inability of the pro-reform parties to adapt to the rules they put in place and not enough de novo job creation, particularly in the early 1990's.

\section{Electoral Rules and Party Coalitions}

The electoral rules promoted by the UD and their coalition partners before the 1993 election were explicitly designed to reduce the number of competing parties by providing very strong incentives for the consolidation of the large number of parties holding seats after the 1991 election. The feeling was that this plethora of parties had contributed directly to the inability to establish a stable coalition government. As it turned out it was the governing coalition that was unable to consolidate. The main elements in the coalition government that fell in May, 1993 were the UD, KLD, and ZChN (Christian National Union). The latter was a church oriented nationalistic party that had campaigned in 1991 as part of a Catholic coalition party. The UD and KLD were virtually identical on all policy questions, particularly regarding the direction of reforms. The $\mathrm{ZChN}$ was more critical of the Balcerowicz policies, though they remained part of the UD led coalition. One might think that given the incentives in the electoral rules that at least the UD and the KLD would coalesce. It is more understandable why the ZChN might not join, as they disagreed with the economic policies and demanded a larger role for church teachings backed by legal force. The UD and KLD, by contrast, included members with a range of views regarding the role of the church and tried to avoid the issue. ${ }^{15}$ All three parties ran separate campaigns in 1993, even knowing that the rules for allocating seats made these decisions risky. In the end, the KLD received only four percent of the vote, less than the necessary five percent threshold. The ZChN joined a Catholic coalition, Catholic Electoral Committee "Fatherland", which received $6.4 \%$ of the vote, but since this was a coalition its threshold for being seated was eight percent so it also did not get any seats.

There are reasons to assume that if the UD and the KLD united prior to the 1993 election, as they did in May, 1994, shortly after the election, that the coalition would have received the sum of the votes each party won individually. This would have been $14.6 \%$ of the vote, making the

strategic voting. The latter assumption is more plausible, as we have maintained the same thresholds.

${ }^{15}$ To illustrate the divisions over the role of the church among UD members, its delegates split on the legislation to prohibit abortions, a major church supported issue. The SLD was quite and explicit and unified in opposing church influence and strongly opposed the limitations on abortions. 
coalition a strong third place finisher $.8 \%$ behind the PSL. Following the d'Hondt formula for allocating seats, the UD/KLD coalition would have received 97 seats, an increase of 23 over what the UD won by itself. The SLD would have lost ten seats and the other parties either three or four seats each. It is harder to argue that the $\mathrm{ZChN}$ might have remained in the "governing" coalition rather than join the Fatherland coalition, given the policy disagreements between its leaders and those in the UD. If they had, however, it would have created a bloc that would have rivaled the SLD for a plurality of the votes and of the seats, which might have been better than no seats at all. 16

\section{Job Creation}

A second factor contributing to the electoral difficulties of the UD/UW was that the de novo job creation was too slow and too small. A counterfactual exercise is to ask what would the distribution of seats have been if there had been more jobs created in new enterprises? Table 4 shows how the national distribution of votes would have differed if job creation had been fifty percent higher. The biggest change is the increased vote share of the UD or UW, largely at the expense of the SLD, with smaller shares coming from the two right wing parties, the Solidarity Trade Union and the KPN in 1993 and the AWS and the ROP in 1997. The leaders of all of these parties had been very critical of market oriented reforms and claimed to want a policy that would maintain the older state enterprises, though with a strong privatization program. ${ }^{17}$ Such policies, though supportive of a private market, do not promote development through de novo firm creation and would mandate a strong role for the government in economic development. The question now is, how would these changes in vote proportions affect the allocation of seats.

Table 6 shows the number of seats expected to go to each party under the more jobs scenarios for both the d'Hondt and Sainte-Laguë seat allocation rules. For 1993 we also show the allocations with the UD separate from the KLD and with their votes combined into a pseudocoalition party. The important observation is that our prediction of the number of additional

\footnotetext{
${ }^{16}$ A more likely scenario is a merger of the Fatherland with the Solidarity Trade Union and the BBWR, the latter being an independent organization initiated by Wałęa. The AWS coalition that won a plurality in 1997 is basically this combination of organizations. If this and the UD+KLD coalitions had emerged prior to the 1993 election rather than after, it would have dramatically restructured the composition of the new parliament, assuming the vote shares had stayed the same. The two differences between this outcome and what transpired in 1997 was that the PSL and UP lost most or all of their seats, with the AWS and SLD being the beneficiaries.

${ }^{17}$ The appeals of these parties is evidenced by the strong association between the proportion of non-farm workers in state-owned enterprisers (included those being restructured but not fully privatized) and the votes for the Solidarity Trade Union in 1993 and the AWS and the ROP in 1997.
} 
seats won by the UD/UW if there had been more new job creation is greater under the d'Hondt rule. Further, the gain to the UD+KLD pseudo-coalition in 1993 from the same amount of new job creation is greater than for the UD by itself. The explanation for why more job creation yields more gains under the d'Hondt formula than under the Sainte-Laguë derives from the greater advantage the d'Hondt formula gives to larger parties. The UD vote is already higher in areas with high rates of job creation, which is also where we would expect the new jobs to be concentrated. The d'Hondt formula gives greater weight to this increased plurality than does the more proportional Sainte-Laguë formula. We ran an ordered probit model for the number of seats gained in each district under the different seat allocation formulas, and there was a larger association between the number of new jobs created and the seat gains under the d'Hondt rule than under Sainte-Laguë. (The estimated equation is presented in Appendix D.)

\section{Table 6: Job Creation and Seat Allocations}

\begin{tabular}{lrrrrrr}
\hline \multicolumn{2}{c}{ d'Hondt } & & & St.-Laguë & \\
\hline Party & Actual & More Jobs & Difference & Actual Jobs & More Jobs & Difference \\
1993 & & & & & & \\
SLD & 171 & 159 & -12 & 150 & 143 & -7 \\
PSL & 132 & 130 & -2 & 112 & 110 & -2 \\
UD & 74 & 92 & +18 & 78 & 92 & +14 \\
UP & 41 & 42 & +1 & 54 & 52 & -2 \\
KPN & 22 & 14 & -8 & 32 & 25 & -7 \\
BBWR & 16 & 19 & +3 & 30 & 34 & +4 \\
1993 & & & & & & \\
SLD & 161 & 147 & -14 & 139 & 130 & -9 \\
PSL & 128 & 119 & -9 & 108 & 104 & -4 \\
UD + KLD & 97 & 128 & +31 & 104 & 122 & +18 \\
UP & 37 & 35 & -2 & 50 & 48 & -2 \\
KPN & 19 & 11 & -8 & 27 & 21 & -6 \\
BBWR & 14 & 16 & +2 & 28 & 31 & +3 \\
1997 & & & & & & \\
AWS & 201 & 195 & -6 & 173 & 172 & -1 \\
SLD & 164 & 151 & -13 & 149 & 140 & -9 \\
UW & 60 & 80 & +20 & 73 & 87 & +14 \\
PSL & 27 & 27 & 0 & 45 & 44 & -1 \\
ROP & 6 & 5 & -1 & 18 & 15 & -3 \\
\hline & & & & & & \\
& & & & & & \\
\end{tabular}


We conclude from this analysis that additional job creation could have made a significant difference in the balance of power in the parliament, with the pro-reform party gaining a much larger share of the seats. As importantly from the standpoint of combining economic and political reform, the results indicate there is an important interaction between the success of the economic transformation and the political rules and strategies in affecting how well the pro-reform constituencies that will accompany successful transitions will be represented. Job creation will be geographically concentrated, so that electoral and representation rules that disadvantage these regions will reduce the influence of the pro-reform constituencies. The pro-reform parties must also realize they are politically vulnerable, particularly at the early stages when the de novo firm creation process is just beginning, and not adopt strategies that dilute their ability to attract voters.

The important lessons from this comparison are, one, that the advantages conveyed by shifts in electoral rules depend upon how those rules change the implicit thresholds for getting seats relative to the parties' vote distributions in the different districts. A second is that because the location of de novo firm and job creation is both geographically concentrated and greater in larger urban areas, rules that advantage urban areas and majority parties in those districts will increase the representation of pro-reform parties. This, of course, is the opposite of the rules adopted in 1993 and 1997, which advantaged larger parties, but those in more rural areas where there is less job creation in de novo firms.

\section{Pro-Reform Parties and the 2001 Election}

The electoral landscape has changed dramatically since the 1997 election victory by the AWS. The UW left the government in August, 2000 after a period of bickering over policy. Given the substantial differences over economic policy between the leaders of the two parties, this might not be a surprise. Then, Aleksander Kwaśniewski, the former leader of the SLD was reelected President in 2000, soundly defeating the AWS leader Marian Krzaklewski and others without even a run-off. The surprising second place finisher, also ahead of Krzaklewski, was Andrzej Olechowski who ran without any party affiliation. Following the election internal conflicts appeared among the leaders of both the UW and the AWS. A division had always existed within the UW (and before it the UD) between more social welfare oriented leaders who were less enthusiastic about the rigorous economic reforms and the economic liberals who promoted the reforms. This disagreement finally split the party in late 2000, with the social reformers taking control. The AWS has further disintegrated, with the Solidarity Trade Union deciding to leave the party and two new parties forming to compete on the right wing. 
Our earlier proposition (Jackson, Klich and Poznańska, 2000b) that the growth of new enterprises creates a constituency that both supports parties pursuing liberal reforms and encouraging the growth of the new sector and constrains other parties from undermining these reforms has become evident in the in the past five months as various political leaders maneuver for advantage leading to the Sept., 2001 elections. The advocacy for an economic development policy based on the encouragement of de novo firm and job creation was adopted explicitly by a new party, the Civic Platform (PO). The leaders of this new party are Andrzej Olechowski, the independent candidate for President; Donald Tusk, Deputy Senate Speaker and former KLD and UW leader; and Maciej Płażyński Sejm speaker and one of the AWS leaders. The Civic Platform's economic plan nicely fits our proposition. In an interview in The Warsaw Voice (Jan. 28, 2001) Olechowski said, "Certainly, we target the middle class and those aspiring toward membership in this class...." And later he said, “...our approach to the economy is the most compatible with entrepreneurs' needs."

Our second contention, that this economic constituency would constrain the actions of other parties, is evidenced in the recent actions of the SLD. In March, 2001 the party held a conference where they hoped to attract entrepreneurs and business leaders by promising to reduce red tape, taxes, and follow other policies to promote the private sector. These are only promises, but they are promises from the party that only a decade earlier was advocating government support for heavy industry and that when they controlled the government was slow to promote privatization and supported wage increases for workers in state managed firms that went way beyond productivity increases and that exceeded wage increases in the private sector (Jackson, Klich and Poznańska, 2000a).

These attempts by the PO and the SLD to appeal to the entrepreneurial class are particularly remarkable when set against the background of the current unemployment rate. After dropping below ten percent in late 1998, the unemployment rate is now close to sixteen percent, which was the peak during the transition in 1992-3. But, instead of calling for more government subsidy and intervention to protect employment in older firms, both parties are claiming they offer the best chance for stimulating job creation among new private enterprises. What each party will do if, or when, it is part of the government is another question, but the relative convergence of the two says a lot about the development of our proposed constituency and its political implications. What the SLD will do and whether the Platform can succeed will be matter of considerable interest and speculation between now and September, 2001 when the elections are held. Recent polls put the Platform in second place with about fourteen percent of the national vote. This proportion compares to forty-six percent for the SLD, twelve percent for the PSL and ten percent 
for the AWS. (The support for the AWS was estimated before the Solidarity Trade Union withdrew, which is likely to reduce this proportion considerably.) It has to be noted that both leading parties are espousing policies to increase entrepreneurship and the de novo sector.

We certainly cannot predict the results of the 2001 election, but based on these poll results and our qualified analysis of the new electoral rules but we can offer some speculations about the next parliament. Under the new rules, the SLD will have a smaller share of the seats in parliament and might be forced to build a coalition government with the smaller parties. The polls giving the SLD nearly fifty percent of the vote and suggested this might be enough to give them a bare majority. The Warsaw Voice (May 13, 2001), for example, predicts that with $46 \%$ of the national vote the SLD would hold 243 seats, a majority of thirteen seats, as opposed to 282

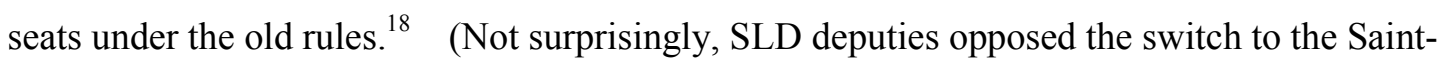
Laguë formula and the removal of the national list.) On the other hand, the new structure may be a large benefit for the right and right-center parties, if they can field competitive lists. The new rules raise the likelihood that the mix of smaller parties on the right could increase their numbers -- if they pass the 5\% vote threshold. The Warsaw Voice predicts sixteen seats for both the UW and the ROP under the new rules, as opposed to one and two seats respectively under the old rules.

These projections ignore the possibility of strategic voting induced by the five percent threshold. It is certainly conceivable that people who express support for the UW or the ROP in a poll may vote differently if their first choice stands a chance of getting less than five percent of the vote. This could lead to defections to the larger parties, but given the differences over economic, social and religious policies it is hard to forecast which parties might benefit. Of course the ultimate irony is that it was a coalition led by the UD leaders, the UW's predecessor, in 1993 that passed the rules designed to increase the advantages for the largest parties, to limit the number of parties in the Parliament, and to force the smaller parties to merge. They are now the ones most likely to benefit by the rules change if they get more than five percent of the vote, or to suffer the most if they fall below this mark. But, with both the SLD and the PO advocating policies to stimulate new enterprises, the seats held by the UW and the right wing parties may be less relevant for economic policy than it would have been eight or even four years ago.

\footnotetext{
${ }^{18}$ The report does not present their methodology for translating votes to seats, which can be complex process and depends heavily on the regional vote distributions, which are not reported.
} 


\begin{tabular}{|c|c|c|}
\hline \multicolumn{3}{|c|}{ Appendix A: Confidence in Private v. State Enterprises } \\
\hline Explanatory Variable & Coefficient & Standard Error \\
\hline Constant & 0.401 & 0.024 \\
\hline 1992 & 0.076 & 0.009 \\
\hline 1993 & 0.037 & 0.008 \\
\hline 1994 & 0.009 & 0.007 \\
\hline 1995 & -0.002 & 0.007 \\
\hline Private Employer & 0.117 & 0.010 \\
\hline Never Worked & 0.063 & 0.009 \\
\hline Joint Stock Company & 0.015 & 0.012 \\
\hline Years of Schooling/10 & 0.083 & 0.009 \\
\hline Log(Income) & 0.016 & 0.004 \\
\hline Age/100 & -0.680 & 0.086 \\
\hline$(\text { Age } / 100)^{2}$ & 0.679 & 0.086 \\
\hline Farmer & 0.077 & 0.008 \\
\hline Village & -0.011 & 0.005 \\
\hline Unemployed & -0.020 & 0.009 \\
\hline \multirow[t]{2}{*}{ Female } & -0.012 & 0.005 \\
\hline & $\mathrm{N}=8910$ & $\mathrm{R}^{2}=0.062$ \\
\hline
\end{tabular}




\begin{tabular}{|c|c|c|c|c|c|c|c|c|}
\hline \multicolumn{9}{|c|}{ Appendix B: Individual Vote Choice Equations } \\
\hline & \multicolumn{4}{|c|}{ SLD } & \multicolumn{4}{|c|}{ PSL } \\
\hline & 1991 & 1993 & 1995 & 1997 & 1991 & 1993 & 1995 & 1997 \\
\hline Communism & $\begin{array}{r}2.79 \\
(0.47)\end{array}$ & $\begin{array}{r}2.49 \\
(0.53)\end{array}$ & $\begin{array}{r}1.79 \\
(0.45)\end{array}$ & $\begin{array}{r}2.90 \\
(0.43)\end{array}$ & $\begin{array}{r}1.70 \\
(0.59)\end{array}$ & $\begin{array}{r}1.81 \\
(0.58)\end{array}$ & $\begin{array}{r}0.48 \\
(0.76)\end{array}$ & $\begin{array}{r}1.25 \\
(0.54)\end{array}$ \\
\hline Confid Pvt & $\begin{array}{c}-1.01 \\
(0.53)\end{array}$ & $\begin{array}{c}-2.43 \\
(0.66)\end{array}$ & $\begin{array}{c}-2.18 \\
(0.51)\end{array}$ & $\begin{array}{r}-2.10 \\
(0.47)\end{array}$ & $\begin{array}{r}-0.06 \\
(0.71)\end{array}$ & $\begin{array}{r}-2.80 \\
(0.72)\end{array}$ & $\begin{array}{r}-1.20 \\
(0.89)\end{array}$ & $\begin{array}{r}-1.84 \\
(0.64)\end{array}$ \\
\hline Church Pwr & $\begin{array}{r}4.28 \\
(0.68)\end{array}$ & $\begin{array}{r}2.67 \\
(0.65)\end{array}$ & $\begin{array}{r}2.25 \\
(0.55)\end{array}$ & $\begin{array}{r}3.94 \\
(0.52)\end{array}$ & $\begin{array}{r}0.88 \\
(0.79)\end{array}$ & $\begin{array}{r}0.45 \\
(0.73)\end{array}$ & $\begin{array}{r}0.21 \\
(1.05)\end{array}$ & $\begin{array}{r}0.89 \\
(0.73)\end{array}$ \\
\hline Farmer & $\begin{array}{r}0.77 \\
(0.67)\end{array}$ & $\begin{array}{r}1.87 \\
(1.12)\end{array}$ & $\begin{array}{r}1.01 \\
(0.77)\end{array}$ & $\begin{array}{r}0.16 \\
(0.63)\end{array}$ & $\begin{array}{r}1.96 \\
(0.42)\end{array}$ & $\begin{array}{r}3.31 \\
(1.05)\end{array}$ & $\begin{array}{r}1.76 \\
(0.83)\end{array}$ & $\begin{array}{r}1.93 \\
(0.59)\end{array}$ \\
\hline Village & $\begin{array}{c}-0.82 \\
(0.40)\end{array}$ & $\begin{array}{r}0.10 \\
(0.35)\end{array}$ & $\begin{array}{r}1.16 \\
(0.33)\end{array}$ & $\begin{array}{r}0.67 \\
(0.29)\end{array}$ & $\begin{array}{r}1.99 \\
(0.38)\end{array}$ & $\begin{array}{r}1.78 \\
(0.33)\end{array}$ & $\begin{array}{r}4.23 \\
(0.81)\end{array}$ & $\begin{array}{r}2.43 \\
(0.37)\end{array}$ \\
\hline UD Candid & $\begin{array}{c}-0.62 \\
(0.30)\end{array}$ & $\begin{array}{c}-1.04 \\
(0.50)\end{array}$ & & $\begin{array}{c}-0.37 \\
(0.27)\end{array}$ & $\begin{array}{c}-0.62 \\
(0.30)\end{array}$ & $\begin{array}{r}-1.04 \\
(0.50)\end{array}$ & & $\begin{array}{r}-0.37 \\
(0.27)\end{array}$ \\
\hline Prty Candid & & $\begin{array}{r}0.73 \\
(0.58)\end{array}$ & $\begin{array}{c}-0.19 \\
(0.53)\end{array}$ & $\begin{array}{r}1.02 \\
(0.41)\end{array}$ & $\begin{array}{r}1.97 \\
(1.22)\end{array}$ & $\begin{array}{r}1.94 \\
(0.56)\end{array}$ & & $\begin{array}{r}0.12 \\
(0.86)\end{array}$ \\
\hline \multirow[t]{3}{*}{ Year $=1993$} & $\begin{array}{r}0.35 \\
(0.23)\end{array}$ & & & & $\begin{array}{r}0.06 \\
(0.30)\end{array}$ & & & \\
\hline & \multicolumn{2}{|c|}{ Catholic Parties } & \multicolumn{2}{|l|}{ Walęsa } & \multicolumn{2}{|c|}{ Solidarity } & & AWS \\
\hline & 1991 & 1993 & 1995 & 1997 & 1991 & 1993 & & 1997 \\
\hline Communism & $\begin{array}{r}0.25 \\
(0.48)\end{array}$ & $\begin{array}{c}-1.57 \\
(1.00)\end{array}$ & $\begin{array}{c}-0.94 \\
(0.45)\end{array}$ & & $\begin{array}{r}0.28 \\
(0.39)\end{array}$ & $\begin{array}{r}1.31 \\
(0.71)\end{array}$ & & $\begin{array}{c}-0.95 \\
(0.38)\end{array}$ \\
\hline Confid Pvt & $\begin{array}{r}-0.27 \\
(0.56)\end{array}$ & $\begin{array}{c}-0.24 \\
(1.14)\end{array}$ & $\begin{array}{r}-1.16 \\
(0.50)\end{array}$ & & $\begin{array}{c}-0.32 \\
(0.43)\end{array}$ & $\begin{array}{r}-2.75 \\
(0.88)\end{array}$ & & $\begin{array}{c}-1.82 \\
(0.41)\end{array}$ \\
\hline Church Pwr & $\begin{array}{r}-4.97 \\
(0.71)\end{array}$ & $\begin{array}{c}-6.36 \\
(1.30)\end{array}$ & $\begin{array}{c}-1.89 \\
(0.55)\end{array}$ & & $\begin{array}{r}-1.26 \\
(0.49)\end{array}$ & $\begin{array}{r}-3.36 \\
(0.97)\end{array}$ & & $\begin{array}{r}-2.70 \\
(0.47)\end{array}$ \\
\hline Farmer & $\begin{array}{r}1.00 \\
(0.49)\end{array}$ & $\begin{array}{r}2.64 \\
(1.30)\end{array}$ & $\begin{array}{r}1.19 \\
(0.76)\end{array}$ & & $\begin{array}{r}0.56 \\
(0.42)\end{array}$ & $\begin{array}{r}0.56 \\
(1.46)\end{array}$ & & $\begin{array}{r}1.10 \\
(0.56)\end{array}$ \\
\hline Village & $\begin{array}{r}0.14 \\
(0.32)\end{array}$ & $\begin{array}{c}-0.51 \\
(0.64)\end{array}$ & $\begin{array}{r}1.02 \\
(0.33)\end{array}$ & & $\begin{array}{r}0.42 \\
(0.24)\end{array}$ & $\begin{array}{r}0.65 \\
(0.41)\end{array}$ & & $\begin{array}{r}0.74 \\
(0.25)\end{array}$ \\
\hline UD Candid & $\begin{array}{c}-0.62 \\
(0.30)\end{array}$ & $\begin{array}{c}-1.04 \\
(0.50)\end{array}$ & & & $\begin{array}{c}-0.62 \\
(0.30)\end{array}$ & $\begin{array}{c}-1.04 \\
(0.50)\end{array}$ & & $\begin{array}{r}-0.37 \\
(0.27)\end{array}$ \\
\hline Prty Candid & & & $\begin{array}{r}0.00 \\
(0.25)\end{array}$ & & & & & $\begin{array}{c}-0.22 \\
(0.29)\end{array}$ \\
\hline Year $=1993$ & $\begin{array}{r}0.11 \\
(0.24) \\
\end{array}$ & & & & $\begin{array}{r}0.66 \\
(0.19) \\
\end{array}$ & & & \\
\hline
\end{tabular}




\begin{tabular}{|c|c|c|c|c|c|c|c|c|}
\hline \multicolumn{9}{|c|}{ Appendix B: Cont. } \\
\hline & \multicolumn{4}{|c|}{ UP } & \multicolumn{4}{|c|}{ Other } \\
\hline & 1991 & 1993 & 1995 & 1997 & 1991 & 1993 & 1995 & 1997 \\
\hline Communism & $\begin{array}{r}1.22 \\
(0.78)\end{array}$ & $\begin{array}{r}1.08 \\
(0.67)\end{array}$ & $\begin{array}{r}0.08 \\
(0.73)\end{array}$ & $\begin{array}{r}0.92 \\
(0.57)\end{array}$ & $\begin{array}{r}0.12 \\
(0.33)\end{array}$ & $\begin{array}{r}0.54 \\
(0.51)\end{array}$ & $\begin{array}{r}-0.64 \\
(0.55)\end{array}$ & $\begin{array}{r}0.75 \\
(0.51)\end{array}$ \\
\hline Confid Pvt & $\begin{array}{r}0.35 \\
(0.91)\end{array}$ & $\begin{array}{c}-1.57 \\
(0.81)\end{array}$ & $\begin{array}{r}-1.81 \\
(0.82)\end{array}$ & $\begin{array}{r}-2.09 \\
(0.66)\end{array}$ & $\begin{array}{c}-0.24 \\
(0.36)\end{array}$ & $\begin{array}{c}-0.61 \\
(0.61)\end{array}$ & $\begin{array}{r}-1.59 \\
(0.61)\end{array}$ & $\begin{array}{r}-0.96 \\
(0.57)\end{array}$ \\
\hline Church Pwr & $\begin{array}{r}-0.90 \\
(1.01)\end{array}$ & $\begin{array}{r}1.14 \\
(0.80)\end{array}$ & $\begin{array}{r}0.82 \\
(0.88)\end{array}$ & $\begin{array}{r}1.32 \\
(0.71)\end{array}$ & $\begin{array}{c}-0.18 \\
(0.40)\end{array}$ & $\begin{array}{r}-1.05 \\
(0.60)\end{array}$ & $\begin{array}{r}-1.04 \\
(0.67)\end{array}$ & $\begin{array}{r}-0.32 \\
(0.65)\end{array}$ \\
\hline Farmer & $\begin{array}{r}-15.43 \\
(3.61)\end{array}$ & $\begin{array}{r}0.77 \\
(1.45)\end{array}$ & $\begin{array}{c}-0.18 \\
(1.29)\end{array}$ & $\begin{array}{r}0.58 \\
(0.77)\end{array}$ & $\begin{array}{r}1.09 \\
(0.35)\end{array}$ & $\begin{array}{r}1.65 \\
(1.09)\end{array}$ & $\begin{array}{r}1.23 \\
(0.83)\end{array}$ & $\begin{array}{r}1.50 \\
(0.62)\end{array}$ \\
\hline Village & $\begin{array}{r}-0.13 \\
(0.56)\end{array}$ & $\begin{array}{c}0.22 \\
(0.42)\end{array}$ & $\begin{array}{r}0.51 \\
(0.50)\end{array}$ & $\begin{array}{r}0.65 \\
(0.37)\end{array}$ & $\begin{array}{r}0.47 \\
(0.20)\end{array}$ & $\begin{array}{r}0.37 \\
(0.31)\end{array}$ & $\begin{array}{r}0.43 \\
(0.39)\end{array}$ & $\begin{array}{r}0.76 \\
(0.33)\end{array}$ \\
\hline UD Candid & $\begin{array}{c}-0.62 \\
(0.30)\end{array}$ & $\begin{array}{c}-1.04 \\
(0.50)\end{array}$ & & $\begin{array}{c}-0.37 \\
(0.27)\end{array}$ & $\begin{array}{c}-0.62 \\
(0.30)\end{array}$ & $\begin{array}{c}-1.04 \\
(0.50)\end{array}$ & & $\begin{array}{c}-0.37 \\
(0.27)\end{array}$ \\
\hline Prty Candid & & $\begin{array}{r}1.16 \\
(0.63)\end{array}$ & & & & & & \\
\hline Year $=1993$ & $\begin{array}{c}-0.53 \\
(0.42)\end{array}$ & & & & $\begin{array}{r}0.35 \\
(0.15) \\
\end{array}$ & & & \\
\hline
\end{tabular}

The model is $\log \left(P_{i j} / P_{i l}\right)=X_{i} B_{j}+U_{i j}$, where $P_{i j}$ is the probability individual $i$ voted for party $j$ and $P_{i l}$ is the probability she or he says they voted for the UD. 
William Davidson Institute Working Paper 391

\begin{tabular}{|c|c|c|c|c|c|c|}
\hline \multicolumn{7}{|c|}{ Appendix C: Estimated Election Outcome Models } \\
\hline & 1993 & 1995 & 1997 & 1993 & 1995 & 1997 \\
\hline & SLD & Kwas & SLD & PSL & Pawlak & PSL \\
\hline New Jobs & $\begin{array}{c}-8.98 \\
(3.05)\end{array}$ & $\begin{array}{c}-2.64 \\
(1.47)\end{array}$ & $\begin{array}{l}-3.15 \\
(1.34)\end{array}$ & $\begin{array}{r}-8.50 \\
(2.97)\end{array}$ & $\begin{array}{c}-5.40 \\
(3.44)\end{array}$ & $\begin{array}{c}-2.19 \\
(1.76)\end{array}$ \\
\hline$\%$ Unemployed & $\begin{array}{r}-0.90 \\
(1.27)\end{array}$ & $\begin{array}{r}-1.06 \\
(0.84)\end{array}$ & $\begin{array}{r}-0.19 \\
(1.60)\end{array}$ & $\begin{array}{c}-0.48 \\
(1.23)\end{array}$ & $\begin{array}{c}-2.72 \\
(1.88)\end{array}$ & $\begin{array}{r}-1.52 \\
(1.97)\end{array}$ \\
\hline$\%$ Jobs in SOEs & $\begin{array}{r}0.01 \\
(0.54)\end{array}$ & $\begin{array}{c}-0.27 \\
(0.29)\end{array}$ & $\begin{array}{r}0.20 \\
(0.51)\end{array}$ & $\begin{array}{r}0.56 \\
(0.52)\end{array}$ & $\begin{array}{r}0.18 \\
(0.65)\end{array}$ & $\begin{array}{r}0.33 \\
(0.63)\end{array}$ \\
\hline$\%$ Farming & & & & $\begin{array}{r}3.08 \\
(0.72)\end{array}$ & $\begin{array}{r}3.42 \\
(0.88)\end{array}$ & $\begin{array}{r}2.01 \\
(0.88)\end{array}$ \\
\hline$\%$ Village & & $\begin{array}{r}0.84 \\
(0.23)\end{array}$ & & $\begin{array}{r}1.87 \\
(0.55)\end{array}$ & $\begin{array}{r}1.80 \\
(0.84)\end{array}$ & $\begin{array}{r}2.69 \\
(0.69)\end{array}$ \\
\hline Schooling & $\begin{array}{r}-0.27 \\
(0.10)\end{array}$ & $\begin{array}{r}-0.17 \\
(0.06)\end{array}$ & $\begin{array}{r}-0.20 \\
(0.09)\end{array}$ & $\begin{array}{c}-0.29 \\
(0.10)\end{array}$ & $\begin{array}{c}-0.21 \\
(0.14)\end{array}$ & $\begin{array}{r}-0.41 \\
(0.12)\end{array}$ \\
\hline Age & $\begin{array}{c}-0.01 \\
(0.06)\end{array}$ & $\begin{array}{c}-0.01 \\
(0.04)\end{array}$ & $\begin{array}{c}-0.03 \\
(0.07)\end{array}$ & $\begin{array}{c}-0.06 \\
(0.06)\end{array}$ & $\begin{array}{r}0.14 \\
(0.09)\end{array}$ & $\begin{array}{r}-0.01 \\
(0.09)\end{array}$ \\
\hline Church Attend & $\begin{array}{c}-2.43 \\
(0.52)\end{array}$ & $\begin{array}{c}-1.90 \\
(0.34)\end{array}$ & $\begin{array}{c}-2.13 \\
(0.47)\end{array}$ & $\begin{array}{c}-2.08 \\
(0.54)\end{array}$ & $\begin{array}{c}-1.54 \\
(0.80)\end{array}$ & $\begin{array}{r}-1.61 \\
(0.66)\end{array}$ \\
\hline UD Candid & $\begin{array}{c}-0.64 \\
(0.19)\end{array}$ & & $\begin{array}{c}-0.20 \\
(0.20)\end{array}$ & $\begin{array}{c}-0.64 \\
(0.19)\end{array}$ & & $\begin{array}{r}-0.20 \\
(0.20)\end{array}$ \\
\hline \multirow[t]{2}{*}{ Prty Candid } & $\begin{array}{r}0.59 \\
(0.19)\end{array}$ & $\begin{array}{r}0.12 \\
(0.13)\end{array}$ & $\begin{array}{r}0.12 \\
(0.23)\end{array}$ & $\begin{array}{r}0.88 \\
(0.20)\end{array}$ & $\begin{array}{r}0.85 \\
(0.32)\end{array}$ & $\begin{array}{r}0.90 \\
(0.28)\end{array}$ \\
\hline & Cath & Wałęsa & ROP & Solid & Solid & AWS \\
\hline New Jobs & $\begin{array}{r}-4.46 \\
(4.29)\end{array}$ & $\begin{array}{r}0.15 \\
(2.48)\end{array}$ & $\begin{array}{r}-3.68 \\
(1.98)\end{array}$ & $\begin{array}{c}-9.32 \\
(3.21)\end{array}$ & & $\begin{array}{r}-2.43 \\
(1.61)\end{array}$ \\
\hline$\%$ Unemployed & $\begin{array}{r}0.29 \\
(1.78)\end{array}$ & $\begin{array}{r}-0.48 \\
(1.40)\end{array}$ & $\begin{array}{r}2.37 \\
(2.41)\end{array}$ & $\begin{array}{c}-0.12 \\
(1.34)\end{array}$ & & $\begin{array}{r}0.04 \\
(1.97)\end{array}$ \\
\hline$\%$ Jobs in SOEs & $\begin{array}{r}-0.30 \\
(0.76)\end{array}$ & $\begin{array}{r}0.41 \\
(0.49)\end{array}$ & $\begin{array}{r}1.71 \\
(0.73)\end{array}$ & $\begin{array}{r}1.51 \\
(0.57)\end{array}$ & & $\begin{array}{r}0.93 \\
(0.59)\end{array}$ \\
\hline Austrian Region & & & $\begin{array}{r}0.29 \\
(0.23)\end{array}$ & & & $\begin{array}{r}0.50 \\
(0.19)\end{array}$ \\
\hline Schooling & $\begin{array}{c}-0.29 \\
(0.13)\end{array}$ & $\begin{array}{c}-0.17 \\
(0.10)\end{array}$ & $\begin{array}{c}-0.39 \\
(0.13)\end{array}$ & $\begin{array}{c}-0.27 \\
(0.10)\end{array}$ & & $\begin{array}{c}-0.35 \\
(0.11)\end{array}$ \\
\hline Age & $\begin{array}{r}0.16 \\
(0.09)\end{array}$ & $\begin{array}{r}0.16 \\
(0.07)\end{array}$ & $\begin{array}{r}0.28 \\
(0.10)\end{array}$ & $\begin{array}{r}0.04 \\
(0.07)\end{array}$ & & $\begin{array}{r}0.11 \\
(0.09)\end{array}$ \\
\hline Church Attend & $\begin{array}{r}2.14 \\
(0.73)\end{array}$ & $\begin{array}{r}2.73 \\
(0.53)\end{array}$ & $\begin{array}{r}-0.06 \\
(1.00)\end{array}$ & $\begin{array}{c}0.91 \\
(0.55)\end{array}$ & & $\begin{array}{r}0.75 \\
(0.82)\end{array}$ \\
\hline UD Candid & $\begin{array}{c}-0.64 \\
(0.19)\end{array}$ & & $\begin{array}{c}-0.20 \\
(0.20)\end{array}$ & $\begin{array}{c}-0.64 \\
(0.19)\end{array}$ & & $\begin{array}{r}-0.20 \\
(0.20)\end{array}$ \\
\hline Prty Candid & & $\begin{array}{r}0.04 \\
(0.15)\end{array}$ & & & & $\begin{array}{r}0.06 \\
(0.23)\end{array}$ \\
\hline
\end{tabular}


William Davidson Institute Working Paper 391

\begin{tabular}{|c|c|c|c|c|c|c|}
\hline \multicolumn{7}{|c|}{ Appendix C: Con't. } \\
\hline & 1993 & 1995 & 1997 & 1993 & 1995 & 1997 \\
\hline & UP & Zieliński & UP & \multicolumn{3}{|c|}{ Other } \\
\hline New Jobs & $\begin{array}{r}-6.26 \\
(2.51)\end{array}$ & $\begin{array}{r}-1.07 \\
(1.53)\end{array}$ & $\begin{array}{c}-2.72 \\
(1.40)\end{array}$ & $\begin{array}{r}-8.70 \\
(2.75)\end{array}$ & $\begin{array}{c}-2.81 \\
(2.72)\end{array}$ & $\begin{array}{c}-4.45 \\
(1.47)\end{array}$ \\
\hline \% Unemployed & $\begin{array}{r}-0.36 \\
(1.08)\end{array}$ & $\begin{array}{c}-0.72 \\
(0.88)\end{array}$ & $\begin{array}{r}0.36 \\
(1.65)\end{array}$ & $\begin{array}{c}-0.43 \\
(1.16)\end{array}$ & $\begin{array}{c}-1.28 \\
(1.57)\end{array}$ & $\begin{array}{r}-0.75 \\
(1.73)\end{array}$ \\
\hline \% Jobs in SOEs & $\begin{array}{r}0.88 \\
(0.45)\end{array}$ & $\begin{array}{r}0.04 \\
(0.30)\end{array}$ & $\begin{array}{r}0.42 \\
(0.52)\end{array}$ & $\begin{array}{r}0.32 \\
(0.49)\end{array}$ & $\begin{array}{r}0.57 \\
(0.54)\end{array}$ & $\begin{array}{r}0.59 \\
(0.54)\end{array}$ \\
\hline \multicolumn{7}{|l|}{$\%$ Farming } \\
\hline \multicolumn{7}{|l|}{$\%$ Village } \\
\hline Schooling & $\begin{array}{c}-0.19 \\
(0.08)\end{array}$ & $\begin{array}{c}-0.04 \\
(0.06)\end{array}$ & $\begin{array}{c}-0.28 \\
(0.09)\end{array}$ & $\begin{array}{c}-0.29 \\
(0.09)\end{array}$ & $\begin{array}{c}-0.25 \\
(0.11)\end{array}$ & $\begin{array}{r}-0.20 \\
(0.09)\end{array}$ \\
\hline Age & $\begin{array}{c}-0.03 \\
(0.05)\end{array}$ & $\begin{array}{r}0.04 \\
(0.04)\end{array}$ & $\begin{array}{c}0.01 \\
(0.07)\end{array}$ & $\begin{array}{r}0.05 \\
(0.06)\end{array}$ & $\begin{array}{c}0.14 \\
(0.07)\end{array}$ & $\begin{array}{r}0.00 \\
(0.08)\end{array}$ \\
\hline Church Attend & $\begin{array}{c}-2.02 \\
(0.43)\end{array}$ & $\begin{array}{c}-0.13 \\
(0.33)\end{array}$ & $\begin{array}{c}-1.37 \\
(0.50)\end{array}$ & $\begin{array}{c}-0.24 \\
(0.47)\end{array}$ & $\begin{array}{r}0.92 \\
(0.59)\end{array}$ & $\begin{array}{r}0.01 \\
(0.52)\end{array}$ \\
\hline UD Candid & $\begin{array}{c}-0.64 \\
(0.19)\end{array}$ & & $\begin{array}{c}-0.20 \\
(0.20)\end{array}$ & $\begin{array}{l}-0.64 \\
(0.19\end{array}$ & & $\begin{array}{r}-0.20 \\
(0.20)\end{array}$ \\
\hline Prty Candid & $\begin{array}{r}0.86 \\
(0.22)\end{array}$ & & & & & \\
\hline
\end{tabular}

The model is $\log \left(V_{i j} / V_{i l}\right)=X_{i} B_{j}+U_{i j}$, where $V_{i j}$ is party $j$ 's share of the vote in district $i$ and $V_{i l}$ is the UD's share in that district. See Jackson, 2001, for a full description of the model. 


\section{Appendix D: Probit Model of Seat Gain with Additional De Novo Jobs}

We estimated a simple probit model of seats gained with both the d'Hondt and Sainte-Laguë seat allocation rules to examine the question of whether adding more jobs systematically led to greater seat gains for the UD under the d'Hondt formula. This estimation pooled the results for 1997, 1993 with just the UD, and 1993 with the UD and KLD, with tests for appropriate dummy variables and interaction terms. The top part of Table D. 1 shows the best statistical model. In this model the relationship between seats gained and the additional number of new jobs is positive for both rules, but is significantly larger with the d'Hondt rule, as indicated by the coefficients of 18.48 on the $\Delta$ New Jobs variable and the coefficient of -4.99 when this variable is interacted with the dummy variable indicating the use of the Sainte-Laguë rule.

\begin{tabular}{lrr}
\hline \multicolumn{3}{l}{ Table D.1: Probit Model of Seat Gain } \\
\hline Variable & Coeff & St. Error \\
\hline Constant & -2.85 & 0.39 \\
1997 & -0.59 & 0.51 \\
1993, UD + KLD & 0.08 & 0.51 \\
\# Seats & 0.17 & 0.04 \\
\# Seats * (Year=1997) & -0.09 & 0.05 \\
\# Seats * (UD + KLD) & 0.05 & 0.06 \\
$\Delta$ New Jobs/Workforce & 18.48 & 3.06 \\
St.-Laguë * $\Delta$ New Jobs & -4.99 & 1.85 \\
Threshold 1 & 2.48 & 0.31 \\
Threshold 2 & 5.10 & 0.98 \\
Goodness of Fit & & Degrees of \\
Model & $\chi^{2}$ & Freedom \\
A. 1997 \& UD + KLD & 4.58 & 2 \\
B. Plus Main Effects & 143.14 & 3 \\
C. Plus Seat Interactions & 10.14 & 2 \\
D. Plus All Interactions & 5.06 & 4 \\
\hline
\end{tabular}

The goodness of fit measures are tests of the model against increasingly richer models. Model A has just a constant term and separate intercepts for 1997 and 1993 with the UD and KLD combined. This is compared to a model with just a constant term, which is predicting the same seat gain in all districts in all three elections. Adding the two dummy variables allows this expected gain to differ by election scenario but not by district. Model B adds the main effects variables of the number of seats in the district, the change in the number of new jobs as a proportion of the workforce, and the interaction between the new jobs variable and the use of the 
Sainte-Laguë rule. These three variables greatly improve the fit of the model, with the $\chi^{2}$ statistic improving by 143.14 with a reduction in the degrees of freedom of only 3 . Model C, shown in the table, adds variables that interact the number of seats in the district with the dummy variables for each election. The results indicate that the expected gain increases as the number of seats in the district increases, for a given increase in new jobs, but this relationship is smaller in the 1997 election than in either of the 1993 election scenarios. The last model, Model D, includes interaction terms for all main variables with the dummy variables for each election scenario. These additional variables did not add significantly to the model and are omitted. 


\section{Bibliography}

Arthur, W., Brian, 1990, ' 'Silicon Valley' Locational Clusters: When Do Increasing Returns Imply Monopoly?" Mathematical Social Sciences, 19:235-51.

Arthur, W., Brian, Y. M. Ermoliev, and Y. M. Kaniovski, 1987. "Path-dependent processes and the emergence of macro-structure. " European Journal of Operational Research, 30:294-303.

Benoit, Kenneth, 2000, "Which Electoral Formula is the Most Proportional? A New Look with New Evidence," Political Analysis, 8:381-388.

Caballero, Ricardo J. and Mohamad L. Hammour, 2000, "Creative Destruction in Development: Institutions, Crises, and Restructuring," Paper prepared for the World Bank 'Annual Bank Conference on Development Economics, Washington, DC, April 18-20, 2000.

Chan, Kenneth Ka-Lok, 1995, "Poland at the Crossroads: The 1993 General Election," EuropeAsia Studies, 47:123-145.

Cichomski, Bogdan and Pawel Morawski. 1998, Polish General Social Surveys: machine readable data file 1992-7. Warsaw: Institute for Social Studies, University of Warsaw.

Dzierżanowski Włodzimierz, 1999, (ed), Report on the Condition of the Small and Medium-Size Enterprise Sector in Poland for the Years 1997-1998, Warsaw, Pl: Polish Foundation for Small and Medium Enterprise Promotion and Development.

Hellman, Joel, S., 1998, "Winners Take All: The Politics of Partial Reforms in Postcommunist Transitions." World Politics. 50(2): 203-234.

Jackson, John, E., 2001, “A Seemingly Unrelated Regression Model for Multiparty Elections,” Political Analysis, 10(1) forthcoming.

Jackson, John, E., Jacek Klich, Krystyna Poznańska and Jósef Chmiel, 1997, "Economic Change in Poland: 1990-1994," Research Bulletin 6: 7-20.

Jackson, John, E., Jacek Klich and Krystyna Poznańska, 2000a, "Nowe Przedsębiorstwa w Transformacji Gospodarki Polskiej," (New Businesses in the Transformation of the Polish Economy), Gospodarki Narodowa, 2000(5/6): 42-77. Reprinted in English in Research Bulletin, 9(2): 23-56.

Jackson, John, E., Jacek Klich and Krystyna Poznańska, 2000b, "Democratic Institutions and Economic Reform: The Polish Case," paper presented to the Annual WDI/CEPR Conference on Transitional Economies, Moscow, Russia, June, 2000.

Jackson, John, E., and Ann Thomas, 1995, "Bank Structure and New Business Creation: Lessons from an Earlier Time," Regional Science and Urban Economics, 25:323-53.

Kołodko, Grzegorz, 2000, From Shock to Therapy, Oxford, UK: Oxford University Press.

Kornai, János, 2000, “Ten Years After 'The Road to a Free Economy': The Author's SelfEvaluation, Paper prepared for the World Bank 'Annual Bank Conference on Development Economics, Washington, DC, April 18-20, 2000.

Krugman, P. 1991, Geography and Trade, Cambridge, MA: MIT Press.

Nowak, Andrzej, Jakub Urbaniak and Leszek Zienkowski, 1994, "Clustering Processes in Economic Transition," Research Bulletin, 3(3):43-61, Warsaw, P1: Polish Central Statistical Office and the Polish Academy of Sciences.

Powers, Denise V. and James H. Cox, 1997, "Echoes from the Past: The Relationship between Satisfaction with Economic Reforms and Voting Behavior in Poland," American Political Science Review, 91: 617-633.

Slay, Ben, 1994, The Polish Economy: Crisis, Reform and Transformation, Princeton, NJ: Princeton University Press.

Tworzecki, Hubert, 1996, Parties and Politics in Post-1989 Poland, (Boulder, CO: Westview Press. 
William Davidson Institute Working Paper 391

Winiecki, Jan, 2000, "Crucial Relationship between the Privatized Sector and the Generic Private Sector in Post-Communist Privatization: Determinants of Economic Performance," Communist and Post-Communist Studies, 33(4): 505-515. 


\section{DAVIDSON INSTITUTE WORKING PAPER SERIES - Most Recent Papers}

The entire Working Paper Series is available at: www.wdi.bus.umich.edu

CURRENT AS OF 10/4/01

\begin{tabular}{|c|c|c|}
\hline Publication & Authors & Date \\
\hline No. 391: Economic Transition and Elections in Poland & $\begin{array}{l}\text { John E. Jackson, Jacek Klich, and } \\
\text { Krystyna Poznańska }\end{array}$ & June 2001 \\
\hline $\begin{array}{l}\text { No. 390: Effects of Bank Insolvency and Strategic Uncertainty on } \\
\text { Corporate Restructuring in Transition Economies }\end{array}$ & Christa Hainz & Aug. 2001 \\
\hline No. 389: Mark-Up Pricing In Bulgarian Manufacturing & $\begin{array}{l}\text { Rumen Dobrinsky, Boyko } \\
\text { Nikolov, and Nikolay Markov }\end{array}$ & June 2001 \\
\hline $\begin{array}{l}\text { No. } 388 \text { Globalization and Firms' Financing Choices: } \\
\text { Evidence from Emerging Economies }\end{array}$ & $\begin{array}{l}\text { Sergio Schmukler and Esteban } \\
\text { Vesperoni }\end{array}$ & May 2001 \\
\hline $\begin{array}{l}\text { No. } 387 \text { The Distributional Impacts of Indonesia's Financial Crisis on } \\
\text { Household Welfare: A “Rapid Response" Methodology }\end{array}$ & $\begin{array}{l}\text { Jed Friedman and James } \\
\text { Levinsohn }\end{array}$ & Sept. 2001 \\
\hline $\begin{array}{l}\text { No. } 386 \text { Corporate Financial Policies and Performance Prior to Currency } \\
\text { Crises }\end{array}$ & $\begin{array}{l}\text { Arturo Bris, Yrjö Koskinen, and } \\
\text { Vicente Pons }\end{array}$ & June 2001 \\
\hline No. 385 Ownership and Productive Efficiency: Evidence from Estonia & Derek C. Jones and Niels Mygind & Aug. 2001 \\
\hline $\begin{array}{l}\text { No. } 384 \text { Forthcoming in: Journal of Economic Perspectives, } \\
\text { "Institutional Determinants of Labor Reallocation in Transition" Vol. } \\
\text { 16, No. 2, Feb. } 2002 \text {. }\end{array}$ & Tito Boeri and Katherine Terrell & June 2001 \\
\hline $\begin{array}{l}\text { No. } 383 \text { Deindustrialisation and Structural Change During the Post- } \\
\text { Communist Transition }\end{array}$ & $\begin{array}{l}\text { Tomasz Mickiewicz and Anna } \\
\text { Zalewska }\end{array}$ & June 2001 \\
\hline No. 382 Markets and Growth & Štěpán Jurajda and Janet Mitchell & July 2001 \\
\hline $\begin{array}{l}\text { No. } 381 \text { Labor Market Discrimination During Post-Communist } \\
\text { Transition: A Monopsony Approach to the Status of Latvia's Russian } \\
\text { Minority }\end{array}$ & Robert S. Chase & Sept. 2000 \\
\hline No. 380 Dollarization of Liabilities in Non-tradable Goods Sector & Frédéric Chabellard & June 2001 \\
\hline $\begin{array}{l}\text { No. } 379 \text { Lessons from the Russian Meltdown: The Economics of Soft } \\
\text { Legal Constraints }\end{array}$ & Enrico Perotti & Mar. 2001 \\
\hline No. 378 Effective Tax Rates in Transition & Vlad Ivanenko & May 2001 \\
\hline $\begin{array}{l}\text { No. } 377 \text { Some Explanations for Changes in the Distribution of } \\
\text { Household Income in Slovakia: } 1988 \text { and } 1996\end{array}$ & $\begin{array}{l}\text { Thesia Garner and Katherine } \\
\text { Terrell }\end{array}$ & May 2001 \\
\hline $\begin{array}{l}\text { No. } 376 \text { Competition and Enterprise Performance in Transition } \\
\text { Economies: Evidence from a Cross-country Survey }\end{array}$ & $\begin{array}{l}\text { Wendy Carlin, Steven Fries, } \\
\text { Mark Schaffer and Paul Seabright }\end{array}$ & May 2001 \\
\hline $\begin{array}{l}\text { No. } 375 \text { Why More is Actually Less: New Interpretations of China's } \\
\text { Labor-Intensive FDI }\end{array}$ & Yasheng Huang & May 2001 \\
\hline No. 374 Economic Fragmentation and FDI in China & Yasheng Huang & May 2001 \\
\hline $\begin{array}{l}\text { No. } 373 \text { Earnings Disparities in the Czech Republic: Evidence of the } \\
\text { Past Decade and Cross-National Comparison }\end{array}$ & Jiri Vecernik & May 2001 \\
\hline $\begin{array}{l}\text { No. } 372 \text { Economic Reform, Democracy and Growth During Post- } \\
\text { Communist Transition }\end{array}$ & Jan Fidrmuc & Mar. 2001 \\
\hline $\begin{array}{l}\text { No. } 371 \text { Do Multinational Enterprises Substitute Parent Jobs for Foreign } \\
\text { Ones? Evidence from Firm Level Panel Data }\end{array}$ & Jozef Konings and Alan Murphye & Apr. 2001 \\
\hline $\begin{array}{l}\text { No. } 370 \text { From Needs to the Market: Changing Inequality of Household } \\
\text { Income in the Czech Transition }\end{array}$ & Jiri Vecernik & Apr. 2001 \\
\hline $\begin{array}{l}\text { No. } 369 \text { Competition and Corporate Governance: Substitutes or } \\
\text { Complements? Evidence from the Warsaw Stock Exchange }\end{array}$ & $\begin{array}{l}\text { Irena Grosfeld and Thierry } \\
\text { Tressel }\end{array}$ & Mar. 2001 \\
\hline $\begin{array}{l}\text { No. } 368 \text { Multinational Corporations as Catalyst for Industrial } \\
\text { Development: The Case of Poland }\end{array}$ & $\begin{array}{l}\text { Carlo Altomonte and Laura } \\
\text { Resmini }\end{array}$ & Feb. 2001 \\
\hline No. 367 A Multi-Task Theory of the State Enterprise Reform & $\begin{array}{l}\text { Chong-En Bai, David D. Li, } \\
\text { Zhigang Tao, and Yijiang Wang }\end{array}$ & Mar. 2001 \\
\hline No. 366a Confidence Building in Emerging Stock Markets & Enrico C. Perotti and Luc Laeven & June 2001 \\
\hline No. 366 Confidence Building in Emerging Stock Markets & $\begin{array}{l}\text { Enrico C. Perotti, Luc Laeven, } \\
\text { and Pieter van Oijen }\end{array}$ & Dec. 2000 \\
\hline
\end{tabular}

